\title{
Ideological and Political Reform based on Modularized Engineering Materials and Machinery Manufacturing Foundation Course
}

\author{
Xueyin Yang ${ }^{1, a}$, Yanxing $\mathrm{Qi}^{2, \mathrm{~b}}$ \\ ${ }^{1}$ School of Mechanical and Vehicle Engineering Linyi University, Shandong 276005, China \\ ${ }^{2}$ School of Automation and Electrical engineering Linyi University Shandong 276005, China \\ axueyinyang@163.com, bqiyanxing@126.com
}

\begin{abstract}
Engineering Materials and Machinery Manufacturing Fundamentals" is the basic discipline of vehicle engineering. In order to realize the seamless combination of knowledge transfer and ideological and political value guidance, the complex knowledge points are modularized reforms, and each module has the advantages of The curriculum ideological and political elements with distinctive professional characteristics have played a role in guiding students' correct value orientation by updating curriculum teaching objectives, reshaping curriculum teaching design, optimizing experimental curriculum ideological and political penetration, and reforming the ideological and political curriculum penetration of curriculum evaluation mode.
\end{abstract}

Keywords: Curriculum Ideology; Engineering Materials and Mechanical Manufacturing Foundation; Teaching Objectives; Teaching Design.

\section{Introduction}

The course "Engineering Materials and Mechanical Manufacturing Fundamentals" is a basic discipline for vehicle engineering majors, and it is particularly important for vehicle majors to master the molding process, material selection and other related knowledge. In order to cultivate a new generation of engineering and technical talents, value guidance is as important as knowledge transfer and ability improvement.

Engineering materials courses are close to the reality of industrial production and are closely integrated with the work of students after graduation. An engineering and technical personnel must abide by laws and regulations, have good professional ethics and professionalism, love their job, and perform their job duties. The cultivation of these basic qualities is the fundamental task of university professional teaching, which should be reflected in the professional teaching system and should be more targeted. As a vehicle engineering teacher, I know the importance of four-year university education for the cultivation of student engineers. The three-foot podium is not only a place to impart academic knowledge, but also to spread the party's policies, promote patriotism, and promote adherence to professional ethics. A position of love and dedication.

China's industry is currently in the stage of transformation and upgrading, and there is an urgent need for knowledgeable, ethical, and responsible engineering and technical personnel. The various steel and non-ferrous metal materials involved in this course have a wide range of applications in national defense and military industry, industrial production and daily life, and are closely related to the national economy and the people's livelihood. Therefore, the teaching content of this course contains rich ideological and political elements and has a strong ideological and political background. Carrying out the ideological and political construction of this course will not only impart professional knowledge and skills, but also guide students' value orientation, which is important for training. Engineering application talents with national sentiment, corporate responsibility and craftsmanship are of great significance [1]. 


\section{Ideological and Political Curriculum Reform based on Modularization}

The foundation of "curriculum ideology" is "curriculum". For any course, there is no good course construction as the foundation, but the ideological and political construction of the course is tantamount to water without a source and a tree without roots. Before the course ideological and political construction of "Engineering Materials and Machinery Manufacturing Fundamentals", the first thing to emphasize is the construction of the course itself. The curriculum content design, teaching organization, and teaching evaluation must be managed and controlled. The course of "Engineering Materials and Mechanical Manufacturing Fundamentals" has many chapters and complex knowledge points, requiring students to master a large number of knowledge points while learning to use them reasonably to solve complex engineering problems. Before the ideological and political construction of the curriculum is launched, it is necessary to integrate and improve the various knowledge points. Therefore, a modular teaching reform is carried out on the course, and the ideological and political elements are excavated from each module and correctly integrated into the curriculum teaching to make it consistent with the content of the curriculum. Close integration is not only conducive to the achievement of teaching goals, but also conducive to the realization of the role of education [2].

Focusing on "innovation and entrepreneurship" and "the close integration of theory and practice", with the strong support of the college leadership, the course team members and trainers will discuss together, starting from the training requirements of high-skilled talents, to strengthen engineering materials and machining the basic quality and ability training is the main line, and a teaching system that integrates learning and doing, and integrating theory and practice is built. In order to solve the problem of complicated knowledge points and numerous chapters, the teaching mode is based on the input shaft of the light truck transmission and adopts modular teaching. The transmission input shaft is divided into two modules according to functionalization. Seven knowledge points for application: material organization, metal heat treatment, steel materials, casting, pressure processing, welding and cutting processing. The cutting processing module is completed in the metal training center, does not occupy class hours. The specific division is shown in Figure 1 for the functional module division of the light truck transmission input shaft and the corresponding knowledge points.

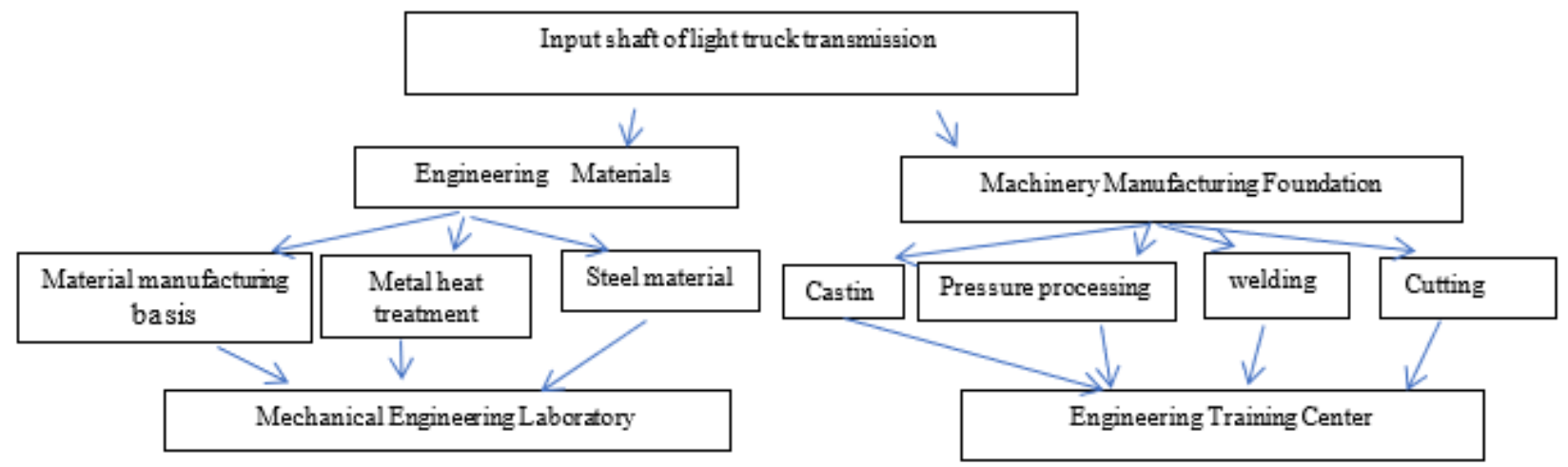

Figure 1. The division of input shaft function modules of light truck transmission and the corresponding diagram of knowledge points

\subsection{Update the Teaching Objectives of the Course}

In view of the characteristics of talent training and the characteristics of students' thinking, perfecting the curriculum teaching system and promoting curriculum teaching reform are important factors to ensure the effectiveness of curriculum ideological and political construction. In order to efficiently improve the effect of ideological and political education, reform the teaching objectives of the curriculum, and seamlessly link the ideological and political education with the curriculum teaching objectives, the specific ideological and political teaching objectives of the course are as follows: 
Curriculum goal 1: Love the motherland, support the leadership of the Communist Party of China, consciously practice the core values of socialism, and firmly establish a correct outlook on the world and life. Be able to see the essence through the phenomenon, and have a good ability to select engineering materials.

Curriculum goal 2: Through experiment and metalworking training: to stimulate students' innovative ability, cultivate students' quality of combining knowledge and practice, and achieve the ability to combine theory and practice.

Curriculum goal 3: Through the infiltration of practical examples and politics into the sub-module courses of casting, casting, pressure processing, welding and cutting processing, cultivate students' national pride and the quality of aspiring to serve the country.

\subsection{Reshaping Curriculum Instructional Design}

Table 1. Teaching case of the course "Engineering Materials and Mechanical Manufacturing Fundamentals"

\begin{tabular}{|c|c|c|c|}
\hline $\begin{array}{l}\text { Module } \\
\text { content }\end{array}$ & Lecture points & $\begin{array}{c}\text { Ideological and political mapping and } \\
\text { integration point }\end{array}$ & $\begin{array}{c}\text { Teaching form and } \\
\text { teaching method }\end{array}$ \\
\hline $\begin{array}{c}\text { Material } \\
\text { organization }\end{array}$ & $\begin{array}{c}\text { The law of crystal } \\
\text { crystallization, phase } \\
\text { diagram, the influence } \\
\text { law of material external } \\
\text { properties and internal } \\
\text { structure. }\end{array}$ & $\begin{array}{l}\text { Introduce "the world's longest bridge-Hong } \\
\text { Kong-Zhuhai-Macao Bridge" new materials } \\
\text { and new technology to be used in bridge } \\
\text { construction to enhance national pride. }\end{array}$ & $\begin{array}{l}\text { Problem-oriented, } \\
\text { on-site teaching, } \\
\text { case teaching } \\
\text { method. }\end{array}$ \\
\hline $\begin{array}{l}\text { Metal heat } \\
\text { treatment }\end{array}$ & $\begin{array}{l}\text { Introduce the structural } \\
\text { transformation of steel } \\
\text { during heat treatment. }\end{array}$ & $\begin{array}{l}\text { In-depth case In 2008, many tower cranes } \\
\text { collapsed in the severe southern blizzard, and } \\
\text { the cause of the sinking of the Titanic. To } \\
\text { enhance students' professional ethics and } \\
\text { sense of responsibility at work. }\end{array}$ & $\begin{array}{l}\text { Online and offline, } \\
\text { case studies, } \\
\text { brainstorming, and } \\
\text { flipped } \\
\text { classrooms. }\end{array}$ \\
\hline $\begin{array}{l}\text { Steel } \\
\text { material }\end{array}$ & $\begin{array}{l}\text { Classification, grades } \\
\text { and applications of iron } \\
\text { and steel materials } \\
\text { Used, the properties and } \\
\text { applications of } \\
\text { commonly used non- } \\
\text { ferrous metals. } \\
\end{array}$ & $\begin{array}{l}\text { Launch the topic of "New Material Industry } \\
\text { Development Guide". Enhance the } \\
\text { professional interest in new materials and the } \\
\text { god of innovation. }\end{array}$ & $\begin{array}{l}\text { Group discussion, } \\
\text { flipped classroom }\end{array}$ \\
\hline Casting & $\begin{array}{c}\text { Introduce the principle, } \\
\text { characteristics and } \\
\text { application of casting } \\
\text { process }\end{array}$ & $\begin{array}{l}\text { Share the successful casting of } 140 \text { tons of } \\
\text { super-large gray iron castings of Jinan No. } 2 \\
\text { Machine Tool, and cultivate the spirit of } \\
\text { teamwork among students. }\end{array}$ & $\begin{array}{l}\text { Case teaching } \\
\text { method, online and } \\
\text { offline. }\end{array}$ \\
\hline $\begin{array}{l}\text { Pressure } \\
\text { processing }\end{array}$ & $\begin{array}{l}\text { Introduce the principle, } \\
\text { characteristics and } \\
\text { application of pressure } \\
\text { processing technology }\end{array}$ & $\begin{array}{l}\text { Analyze the research and development of the } \\
\text { 315MN die forging hydraulic press to promote } \\
\text { die forging of the overall frame of the aircraft, } \\
\text { and cultivate students' spirit of technological } \\
\text { innovation and self-inspiration. }\end{array}$ & $\begin{array}{l}\text { Group discussion, } \\
\text { flip the classroom. }\end{array}$ \\
\hline Welding & $\begin{array}{l}\text { Introduce the principle, } \\
\text { characteristics and } \\
\text { application of welding } \\
\text { process }\end{array}$ & $\begin{array}{l}\text { It is analyzed that the Panlong on the bronze } \\
\text { seat of the tomb of Zenghouyi during the } \\
\text { Spring and Autumn Period and the Warring } \\
\text { States Period is connected by segmented } \\
\text { brazing, which is similar in composition to } \\
\text { modern solder, which enhances the students' } \\
\text { sense of pride in the splendid Chinese culture. }\end{array}$ & $\begin{array}{l}\text { Case pedagogy, } \\
\text { brainstorming, } \\
\text { online and offline. }\end{array}$ \\
\hline
\end{tabular}

Classroom teaching is the main channel for curriculum ideological and political construction. Curriculum teaching reform involves many aspects such as teaching syllabus, training plan, teaching goal, teaching methods and methods, and teaching media. First, we must strengthen the construction of teaching materials and courses. The curriculum system is optimized in accordance with the 
modular setting, and demonstration courses are built relying on the Ministry of Education and the provincial new engineering education reform project. Fully excavate the ideological and political education resources contained in the course, be good at integrating ideological and political elements into the teaching of the course [3], guide students to cultivate and shape correct values "genetic", and use Marxist philosophy Recognize things, analyze problems, and transform the world with standpoints. For example, through the toughness theory and defect theory of the learning materials, students are guided to establish a life outlook that correctly recognizes their own strengths and weaknesses, correctly face setbacks in life, firmly believe that "whatever has a will is achieved", and achieve dreams through hard work.

Introduce specific examples in the classroom teaching process [3], tell stories in the way of storytelling, you can tell the history of material development in China, the story of Guo Shi Wushuang, and the story of the gap between Chinese industry and developed countries in the world to stimulate Students' pursuit of a technological power. The specific module content and ideological and political mapping integration points are shown in Table 1. It is necessary to strengthen the deep integration of information technology and teaching to promote the classroom teaching revolution. Use the visual features of multimedia to integrate the documentary clips of "Great Country Craftsman" and "Intelligent Building a Powerful Country" into classroom teaching. It can also incorporate events that promote the development of materials and the tireless dedication of the predecessors in scientific research and teaching. Deeds are shared to stimulate students' interest and potential in learning, enhance students' recognition of their profession and sense of professional belonging, and cultivate students' recognition and sense of mission for the profession's future career [4]. For example, low resource consumption, low environmental pollution, high technology content, and good economic efficiency have become the mainstream of today's social development. Artificial intelligence such as big data, blockchain, and AI has been applied to certain aspects of material processing. Green manufacturing has become a new development direction, in order to guide students to strengthen the importance of green environmental protection, cultivate students' new development concepts, and establish the green concept of "green water and green mountains are golden mountains and silver mountains".

\subsection{Optimize the Ideological and Political Penetration of Experimental Courses}

High-quality experimental teaching is an important way to promote the quality of course teaching. In order to improve the effect of experimental teaching and increase practical ability, ideological and political reforms are carried out in terms of experimental arrangement and experimental content [1]. There are four experiments in the course of "Engineering Materials and Mechanical Manufacturing Fundamentals", and each experiment occupies 2 class hours. Experimental teaching makes full use of demonstrations, experiments and multimedia teaching methods to guide students to invest time and energy, check materials, and choose plans. In addition, the characteristics of the experimental objects lead students to reflect on how to deal with shocks and compressions, which should be used as experimental facilities in our country. What should be done when it is lower than the foreign experimental facilities in the same field, the pre-class experimental design plan should be submitted to the instructor for review in time. During the experiment, he used his hands and brains to continuously improve the plan to solve the problem. Check and supervise in the classroom, summarize and comment after the experiment, and spot check and student comment before the next experiment, so that students can master it as soon as possible. Cultivate students' ability to solve database application problems and meet the requirements of "Course Goal 1", "Course Goal 2" and "Course Goal 3".

\subsection{Promote Curriculum Ideological and Political Innovation}

In addition to the integration of ideological and political infiltration in modular curriculum teaching, the information explosion era in the "Internet + " era [2] promotes the convenience of network information sharing and real-time communication, promotes ideological and political 
innovations in curriculum teaching models, and truly realizes online The knowledge learning is unlimited and endless; it makes teacher-student interaction, teacher-teacher interaction, and studentstudent interaction more convenient and free, and further creates a good learning atmosphere. Class teachers can optimize and integrate network resources and use social platforms for teaching design and interaction. Online courses and high-quality courses platforms include China MOOC University, Xuetang Online, Excellent Course Alliance, etc. Online teaching platforms include Yu Class, Chaoxing Xuetong, Tencent Class, Dingding Class, etc., and interactive platforms include WeChat, QQ and Campus Today, etc. Use the above-mentioned network tools to carry out teaching organization, design and reform. Select fresh cases that are close to student life, close to student reality, close to professional courses, and further integrate teaching content, carefully design teaching plans, select ideological and political elements, do not speak empty words, do not show great reason, and use simple and easy-to-understand the big vernacular speaks clearly the obscure principles. In addition, you can make full use of extracurricular time to think deeply about the ideological and political teaching cases in the classroom. For example, divide students into different learning interest groups, guide them to further review literature after class, and show their understanding and cognition in the form of writing essays, ideological and political reports, etc., and then through QQ and WeChat class groups, $\mathrm{Yu}$ Classroom discussion area and other platforms to carry out learning discussions between groups to further deepen the learning results.

\section{Conclusion}

Curriculum ideological and political work is an important part of the ideological and political work of colleges and universities. Through the construction of the curriculum system, the value meaning of each course is explored, teaching and educating people are implemented to ensure the smooth realization of the training goals of socialist universities. "Engineering Materials and Machinery Manufacturing Fundamentals", as a basic course for vehicle engineering majors, contains rich and distinctive ideological and political elements. On the basis of fully excavating the characteristic ideological and political elements of vehicle manufacturing, scientifically and rationally design professional knowledge points and The connection and integration of ideological and political education knowledge points, combined with a variety of teaching methods, will naturally lead the value to the professional teaching, and the evaluation and reform of the curriculum ideological and political integration effect, and the ideological and political infiltrate into the usual grades, mid-term exams and final exams In each link, the students' interest in learning the course has been fully mobilized and their love for the major has been enhanced.

\section{References}

[1] Xueyin Yang. Application of Blended Teaching in "Engineering Materials and Machinery Manufacturing Fundamentals". Agricultural Machinery Use and Maintenance, 2019, 4:73-74.

[2] Jian An, Jianchen Li. Exploration of the teaching method reform of the "Engineering Materials" course for mechanical and automotive majors. Education Teaching Forum, 2019(8): 114-115.

[3] Hongli Liu, Bo Gao, Jing Li. Ideological and Political Construction and Evaluation of the Course "Basics of Materials Science and Engineering". Forum on Higher Education, 2020(11): 31-33.

[4] Chunfeng Wan. Research on the path of ideological and political construction of the course "Mechanical Engineering Materials and Thermal Processing Fundamentals". Journal of Wuhan Institute of Shipbuilding Technology, 2021(1): 130-132.

[5] Yuhui Luo, Lin Liu, Dongen Zhang. Ideological and political education design, exploration and practice in the course of "Materials Science and Engineering Fundamentals". Guangdong Chemical Industry, Volume 22, Volume 47, Volume 432, Issue 22, 2020: 167,177. 